Article

\title{
Impacts of Climate Change on the Precipitation and Streamflow Regimes in Equatorial Regions: Guayas River Basin
}

\author{
Mercy Ilbay-Yupa ${ }^{1, *(\mathbb{D}}$, Franklin Ilbay ${ }^{2}$, Ricardo Zubieta ${ }^{3}{ }^{\circledR}$, Mario García-Mora ${ }^{4}$ and Paolo Chasi ${ }^{1}(\mathbb{C}$ \\ 1 Facultad de Ciencias Agropecuarias y Recursos Naturales, Universidad Técnica de Cotopaxi (UTC), \\ Latacunga 050150, Ecuador; wilman.chasi@utc.edu.ec \\ 2 Programa de Maestría en Ciencias con Mención en Hidráulica, Universidad Nacional de Ingeniería, \\ Lima 15012, Peru; luis_5840@hotmail.com \\ 3 Subdirección de Ciencias de la Atmósfera e Hidrósfera (SCAH), Instituto Geofísico del Perú (IGP), \\ Lima 15012, Peru; rzubieta@igp.gob.pe \\ 4 Carrera de Tecnología Superior en Floricultura, Instituto Superior Tecnológico Cotopaxi, \\ Latacunga 050150, Ecuador; gvictormario@hotmail.es \\ * Correspondence: mercy.ilbay@utc.edu.ec
}

Citation: Ilbay-Yupa, M.; Ilbay, F.; Zubieta, R.; García-Mora, M.; Chasi, P. Impacts of Climate Change on the Precipitation and Streamflow Regimes in Equatorial Regions: Guayas River Basin. Water 2021, 13, 3138. https://doi.org/10.3390/ w13213138

Academic Editor: Young Gu Her

Received: 3 August 2021

Accepted: 29 October 2021

Published: 8 November 2021

Publisher's Note: MDPI stays neutral with regard to jurisdictional claims in published maps and institutional affiliations.

Copyright: (c) 2021 by the authors. Licensee MDPI, Basel, Switzerland. This article is an open access article distributed under the terms and conditions of the Creative Commons Attribution (CC BY) license (https:// creativecommons.org/licenses/by/ $4.0 /)$.

\begin{abstract}
The effects of climate change projected for 2050 to 2079 relative to the 1968-2014 reference period were evaluated using 39 CMIP5 models under the RCP8.5 emissions scenario in the Guayas River basin. The monthly normalized precipitation index (SPI) was used in this study to assess the impact of climate change for wet events and droughts from a meteorological perspective. The GR2M model was used to project changes in the streamflow of the Daule River. The climate projection was based on the four rigorously selected models to represent the climate of the study area. On average, an increase in temperature $\left(\sim 2{ }^{\circ} \mathrm{C}\right)$ and precipitation $(\sim 6 \%)$ is expected. A $7 \%$ increase in precipitation would result in a 10\% increase in streamflow for flood periods, while an $8 \%$ decrease in precipitation could result in approximately a $60 \%$ reduction in flow for dry periods. The analysis of droughts shows that they will be more frequent and prolonged in the highlands (Andes) and the middle part of the basin. In the future, wet periods will be less frequent but of greater duration and intensity on the Ecuadorian coast. These results point to future problems such as water deficit in the dry season but also increased streamflow for floods during the wet season. This information should be taken into account in designing strategies for adaptation to climate change.
\end{abstract}

Keywords: climate change; droughts; Guayas; Ecuador; impacts

\section{Introduction}

Climate change is one of the main threats to the planet and constitutes a challenge for the sustainable management of water resources [1,2]. It also plays an important role in social development and global economic growth. In the future, changes in the spatial and temporal patterns of rainfall are expected, leading to an increase in extreme weather events [3-6]. These impacts are also expected to manifest in hydrological regimes, which influence the spatial and temporal patterns of water resources $[7,8]$. All these climate projections were derived from a variety of climate change models [3,9-12]. Global climate models (GCMs) are mathematical models that integrate components of the Earth, atmospheric and ocean climate systems according to physical, chemical and biological principles to simulate climate with respect to $\mathrm{CO}_{2}$ emission conditions [13]. GCMs are generally used to understand the current climate and project climate change, allowing robust decisions to be made based on a wide range of possible futures [14]. The reliability of scenarios generally depends on their ability to represent climate processes [15], the type of emission scenario [16] and model structure [17]. The reliability of some GCMs and regional circulation models in equatorial regions, as a first approximation, has already been characterized by [18]. 
The impacts of droughts in an area are assessed based on changes of frequency, duration and intensity [19]. There are several studies that have analyzed meteorological droughts in relation to cumulative precipitation shortages during wet season onset [20]. Droughts characterized can severely alter the hydrologic regime [21], affect river water quality and impact aquatic ecosystems [22]. The severity and frequency of climatic events such as droughts and floods will change in the future due to global warming, severely affecting the natural environment [23]. Increases in rainfall can cause events such as floods and landslides, among others [24]. Floods are very costly natural disasters [25] that strongly affect the population and economic development, leading to increased vulnerability [26].

Land use changes and climate change are dominant processes that affect hydrological processes such as evapotranspiration, interception and infiltration, resulting in alterations of surface and groundwater flows $[27,28]$. The availability of water resources is decreasing due to population growth [29]. Understanding changes in the course of climate would make it possible to design more effective policies for adaptation in a changing climate [30]. Developed countries, which are the main contributors of greenhouse gases, should focus on mitigation, while developing countries should work on adaptation.

Ecuador is a country that has experienced climatic changes, such as increased temperatures and rainfall, which have had visible impacts, including the melting of glaciers. Increases in average annual temperature and precipitation of $2-3^{\circ} \mathrm{C}$ and $3 \%$, respectively, are expected for the period 2030-2049 [31]. This represents substantially higher temperature increases than the global average [32]. However, there are few basin-scale studies in equatorial regions that provide crucial local details and information for management, prudent environmental protection and planning of economic and social activities [33]. The Guayas River basin is one of the most important in Ecuador and is home to approximately $40 \%$ of the population. This area has been impacted by severe and prolonged extreme events that have had destructive effects on the economy, food security, infrastructure and ecosystems [34-36]. The objective of this research was to characterize the impacts of climate change on the dynamics of precipitation, temperature and streamflow in the Guayas River basin.

\section{Materials and Methods}

\subsection{Study Area}

The Guayas River basin is located in the central-western part of Ecuador and is one of the country's main river basins. It covers an area of approximately $32,890 \mathrm{~km}^{2}$ and drains into the Gulf of Guayaquil, with an average annual discharge of $200 \mathrm{~m}^{3} / \mathrm{s}$ for the dry season, increasing to $1600 \mathrm{~m}^{3} / \mathrm{s}$ during the wet season [37]. The two main rivers are the Daule and Babahoyo, which merge into the Guayas River near Guayaquil, the largest and most populated city in Ecuador, with an area of $1800 \mathrm{~km}^{2}$ and a population of 3.645 million [38].

Average annual precipitation is around $1800 \mathrm{~mm}$, and $89 \%$ of total precipitation occurs during the wet season, from December to May [36,39]. The basin has two homogeneous precipitation regions. The first is located in the high mountain zone and is classified as a region of low erosivity. The second, the coastal region, is a region of high aggressiveness, with greater erosive potential and sedimentation problems in the lower part of the basin due to the erosive capacity of rainfall [40]. The Guayas River basin has been affected by extreme phenomena such as El Niño [41], which caused flooding in 1965, 1972, 1973, 1976, 1983, 1987, 1992 and 1998 [36,39,42], and La Niña [43]. The lower part of the basin has greater exposure to flooding [44]. This basin contains the Daule-Peripa reservoir, with an area of $\approx 30,000 \mathrm{ha}, 6$ billion $\mathrm{m}^{3}$ of water storage capacity and discharge of 14,350 $\mathrm{m}^{3} / \mathrm{s}$, which supplies drinking water to Guayaquil and cities bordering the Daule River. The reservoir was built in 1987 to generate electricity, supply water for irrigation, control floods and provide drinking water [45]. The basin has high agricultural potential; its main products include subsistence and export crops, livestock and shrimp [36]. 


\subsection{Data}

\subsubsection{Meteorological and Hydrological Data}

The database includes monthly rainfall and temperature records from meteorological stations and a hydrological station managed by INAMHI (National Meteorological and Hydrological Institute of Ecuador) (Table 1). The selected stations contain information from at least 30 years during the period 1968-2014. There are 16 stations located at altitudes below 1500 masl (Pacific Coast), and 11 stations are in the mountain region (Figure 1). A rigorous quality check of these data was performed using the regional vector method. More details about this analysis can be found in [46].

\subsubsection{GCMs Data}

Monthly temperature and precipitation variables simulated from 39 models of the Coupled Model Intercomparison Project 5 (CMIP5), under the high emission concentration scenario RCP8.5, were used. These are available online (https:/ / climexp.knmi.nl/start.cgi, accessed on 2 October 2020) for the period 1850 to 2100 . These models provide a series of simulated future climate variables that characterize the coming decades or centuries. These can be used as a basis for exploring the impacts of climate change on policy issues of interest and relevance to society [10]. To highlight the largest impacts of climate change (i.e., considering the largest change in temperature, radiative forcing $\left(>8.5 \mathrm{~W} / \mathrm{m}^{2}\right)$ and concentrations ( $\left.>1370 \mathrm{CO}_{2} \mathrm{ppm}\right)$ for 2100 [47], the Representative Concentration Pathway 8.5 (RCP8.5) scenario was selected. This RCP has also been used to evaluate climate change in droughts [48] and hydroelectric power generation [49] in Ecuador.

Table 1. Meteorological stations and hydrology of the Guayas River basin.

\begin{tabular}{|c|c|c|c|c|c|c|}
\hline \multirow{2}{*}{ Name } & \multirow{2}{*}{$\begin{array}{c}\text { Latitude } \\
\left({ }^{\circ} S\right)\end{array}$} & \multirow{2}{*}{$\begin{array}{c}\text { Longitude } \\
\left({ }^{\circ} \mathrm{W}\right)\end{array}$} & \multirow{2}{*}{$\begin{array}{l}\text { Altitude } \\
\text { (masl) }\end{array}$} & \multicolumn{3}{|c|}{ Period } \\
\hline & & & & Precipitation & Temperature & Streamflows \\
\hline Salinas-Bolívar & -1.40 & -79.02 & 3600 & 1968-2014 & & \\
\hline Achupallas-Chimborazo & -2.28 & -78.77 & 3178 & $1968-2014$ & & \\
\hline Pangor-J.de Velasco & -1.83 & -78.88 & 3109 & 1969-2014 & & \\
\hline Cañi-limbe & -1.77 & -78.99 & 2800 & 1977-2014 & & \\
\hline Guasuntos & -2.23 & -78.81 & 2438 & $1972-2014$ & & \\
\hline Compud & -2.34 & -78.94 & 2402 & 1968-2014 & & \\
\hline Chillanes & -1.98 & -79.06 & 2330 & $1968-2014$ & 1982-2014 & \\
\hline Alausi & -2.2 & -78.85 & 2267 & 1968-2014 & & \\
\hline San Antonio-Monjas River & -1.58 & -79.13 & 2200 & $1980-2014$ & & \\
\hline Chunchi & -2.28 & -78.92 & 2177 & $1968-2014$ & 1982-2014 & \\
\hline Pallatanga & -2.00 & -78.97 & 1523 & $1968-2014$ & & \\
\hline Ramón Campaña & -1.12 & -79.09 & 1462 & 1968-2014 & & \\
\hline Chimbo Pj Pangor & -1.94 & -79.00 & 1452 & 1968-2014 & & \\
\hline Sto. Domingo Airport & -0.25 & -79.20 & 554 & $1968-2098$ & & \\
\hline Bucay & -2.20 & -79.13 & 480 & $1968-2000$ & & \\
\hline Las Delicias-Pichincha & -0.26 & -79.40 & 340 & $1968-2003$ & & \\
\hline Puerto Ila & -0.48 & -79.34 & 319 & 1968-2014 & 1970-2014 & \\
\hline Echeandia & -1.43 & -79.29 & 308 & $1968-2014$ & & \\
\hline San Juan La Mana & -0.92 & -79.25 & 215 & $1968-2014$ & & \\
\hline Colimes de Pajan & -1.58 & -80.51 & 200 & 1970-2014 & & \\
\hline Camposano \#2 & -1.59 & -80.40 & 113 & 1977-2014 & 1982-2014 & \\
\hline Pichilingue & -1.07 & -79.49 & 81 & 1968-2014 & 1978-2014 & \\
\hline Ingenio San Carlos & -2.22 & -79.41 & 63 & $1968-2014$ & & \\
\hline Milagro (Ingenio Valdez) & -2.12 & -79.60 & 23 & 1968-2014 & 1970-2014 & \\
\hline Pueblo Viejo & -1.52 & -79.54 & 19 & $1968-2014$ & $1984-2014$ & \\
\hline Vinces INAMHI & -1.56 & -79.77 & 14 & 1968-2014 & & \\
\hline La Capilla INAMHI & -1.70 & -80.00 & 7 & $1968-2014$ & & \\
\hline Daule en la Capilla & 1.69 & 79.99 & 13 & & & 1982-2014 \\
\hline
\end{tabular}



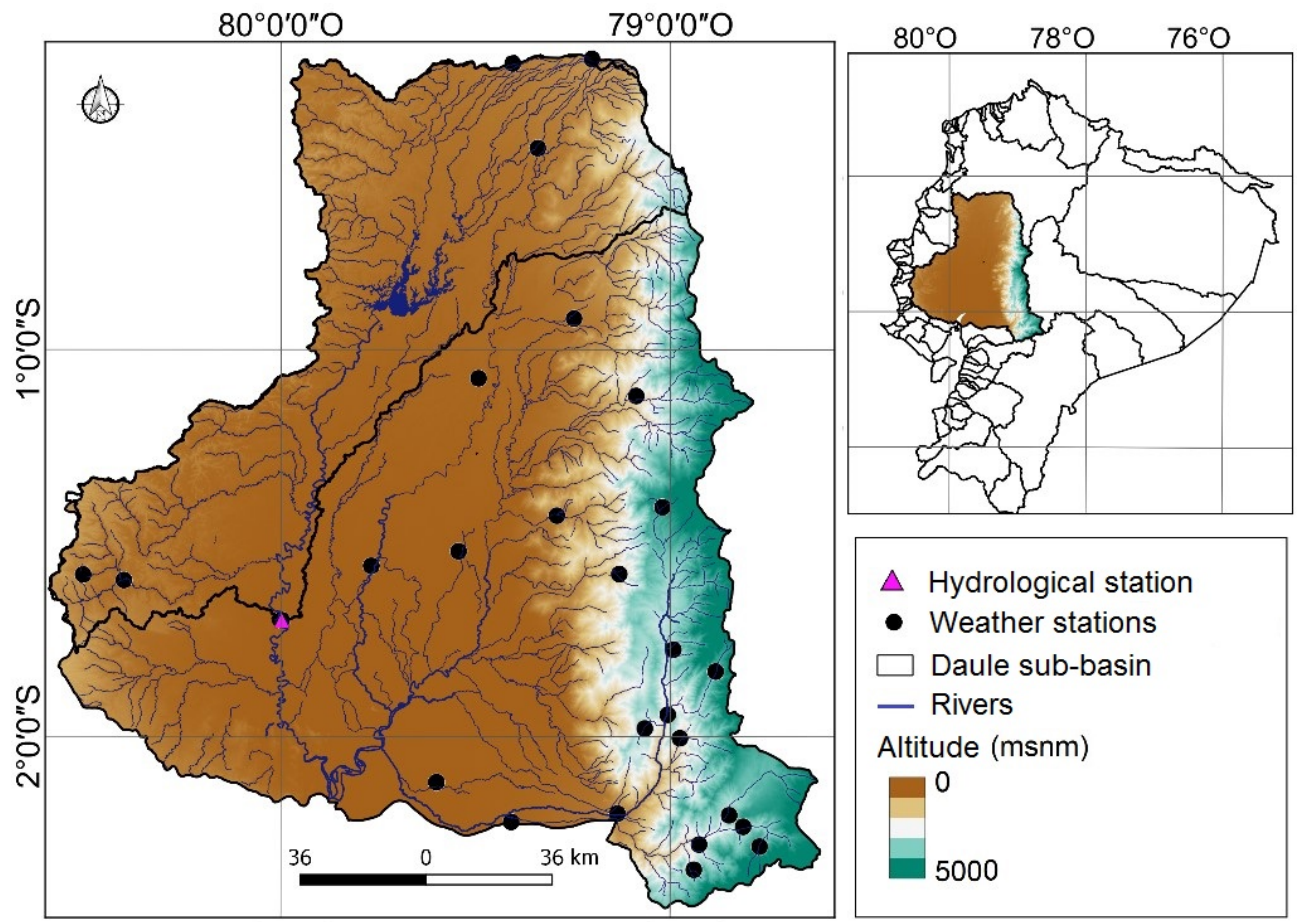

$\triangle$ Hydrological station

- Weather stations

$\square$ Daule sub-basin

- Rivers

Altitude (msnm)

0

5000

Figure 1. Location of the Guayas River basin, showing altitude and distribution of meteorological and hydrological stations.

\subsection{Methodology}

The methodology comprised four phases: (i) Collection, processing and analysis of temperature, observed precipitation and discharge data for the 1968-2014 (baseline scenario) and 2050-2079 (future) GCMs in the Guayas River basin. (ii) Correction and validation of monthly data for the 39 GCMs. (iii) Analysis of delta changes, wet and drought events (SPI) and hydrological modeling (GR2M). (iv) Determining the impacts of climate change (Figure 2).

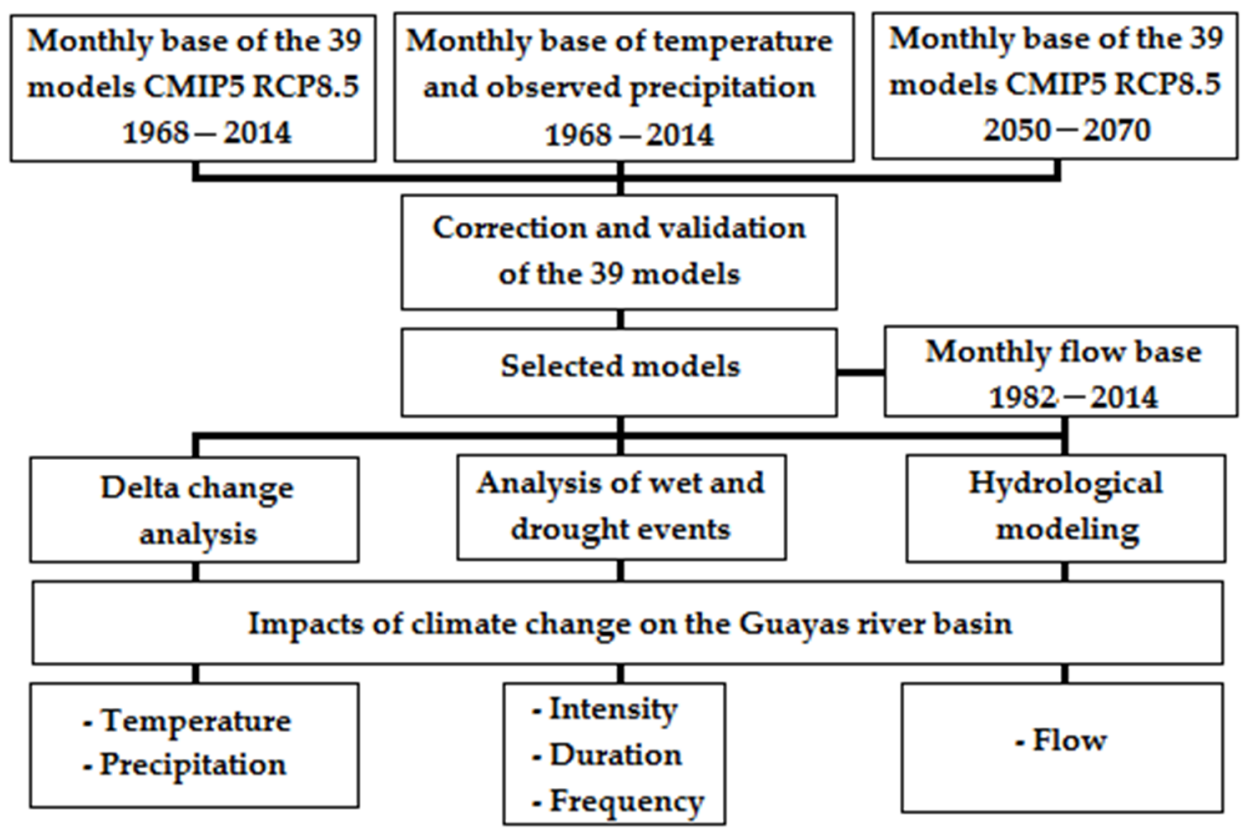

Figure 2. Diagram of the methodological phases of the climate change impact assessment in the Guayas River basin. 


\subsubsection{Assessment of GCMs}

Future predictions in the basin were based only on the models that were able to simulate the observed characteristics of the climate system. For this purpose, the 39 GCMs were evaluated using the Taylor diagram. This design provides a concise statistical summary of the patterns that coincide with the correlation coefficient $(R)$, root mean square difference (RMSE) and the ratio of their variances. These statistics facilitate the determination of how much of the overall RMSE difference in the patterns is attributable to a difference in variance and how much is due to poor pattern correlation of observed to simulated values, based on Equations (1) and (2) [48]. The plot is widely used to evaluate or to track changes in the performance of complex models such as geophysical phenomena [23,49-51].

$$
\operatorname{RMSE}^{2}=\sigma_{f}^{2}+\sigma_{r}^{2}-2 \sigma_{f} \sigma_{r} R
$$

where $\sigma_{f}^{2}$ and $\sigma_{r}^{2}$ are the variances of the test and reference fields, respectively. The construction of the diagram is based on the similarity of the above Equation and the Cosine Law:

$$
c^{2}=a^{2}+b^{2}-2 a b \cos \varnothing
$$

The selection of the best temperature and precipitation GCMs in comparison to observed dataset was performed using the skill score $(S)$ for each model. The skill score varies from zero (least skillful) to one (most skillful) and is defined as shown in Equation (3) [48]:

$$
S=\frac{4(1+R)^{4}}{\left(\hat{\sigma}_{f}+1 / \hat{\sigma}_{f}\right)^{2}\left(1+R_{0}\right)^{4}}
$$

where $S=$ ability score of the models; $R=$ Pearson's correlation coefficient; $\hat{\sigma}_{f}=\sigma_{f} / \sigma_{r}=$ normalized standard deviation; and $R_{0}=$ maximum correlation achievable.

\subsubsection{Precipitation and Temperature Correction}

The adjustment between the observed and simulated (base) monthly mean data during the historical period (1968-2014) was performed using the monthly mean data correction [52], where the temperature is obtained by adding to the entire time series a constant displacement called " $C$ ", which is equal to the average difference between observations and simulations during the reference period (Equation (4)). It is important to note that for average monthly temperature of the basin, only information from 1982 to 2014 was used, as that was the period for which data were available.

$$
\widetilde{T}_{G C M \text { Bas. }}=C+T_{G C M \text { Bas. }}
$$

where $\widetilde{T}_{G C M}$ Bas. and $T_{G C M}$ Bas. are the corrected and uncorrected base temperatures of the models, respectively. The coefficient " $C$ " is obtained as follows:

$$
C=\frac{\sum_{i=1}^{n} T_{\text {Obs. }}-\sum_{i=1}^{n} T_{G C M ~ B a s .}}{n}
$$

where $T_{O b s}$. is the observed temperature in the Guayas River basin, and $n$ is the number of years of analysis.

The mean monthly precipitation was obtained by means of a multiplicative factor differentiated for each month (Equation (6)):

$$
\widetilde{P}_{G C M \text { Bas. }}=C * P_{G C M \text { Bas. }}
$$

where $\widetilde{P}_{M C G \text { Bas. }}$ and $P_{M C G \text { Bas. }}$ are the base, corrected and uncorrected rainfall of the models, respectively. The coefficient " $C$ " is obtained with the following Equation:

$$
\mathrm{C}=\sum_{i=1}^{n} P_{\text {Obs. }} / \sum_{i=1}^{n} P_{G C M} \text { Bas. }
$$


where $P_{\text {Obs. }}$ is the precipitation observed in the Guayas River basin.

Subsequently, the performance of the 39 monthly models was evaluated with the observed data for the temperature and precipitation variables, using the Taylor diagram as indicated above.

\subsubsection{Delta Change Analysis}

This analysis is conducted by transferring the mean monthly change between the GCMs for the base period (1968-2014) and future scenario (2050-2079) to the series observed in the basin stations (1968-2014) for the temperature, precipitation and evapotranspiration variables, using the Equations proposed by [53]:

$$
\begin{gathered}
T_{\text {Fut. }}=T_{\text {Obs. }}+\left(\overline{T_{G C M \text { Bas. }}}-\overline{T_{G C M ~ F u t .}}\right) \\
P_{\text {Fut. }}=P_{\text {Obs. }} *\left(\overline{P_{\text {GCM Fut. }}} / \overline{P_{\text {GCM Bas. }}}\right)
\end{gathered}
$$

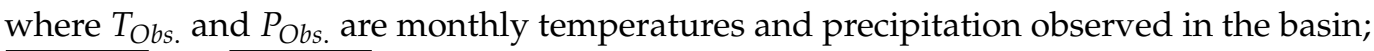

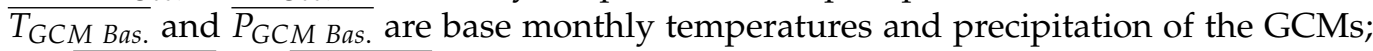

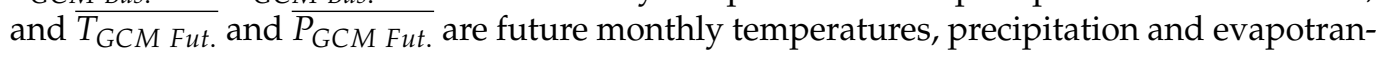
spiration of the GCMs.

\subsubsection{Wet Periods and Drought Analysis}

The standardized precipitation index (SPI) at a monthly time scale (SPI-1), which is based on precipitation datasets [54], was used for 27 observed precipitation time series for the observed period (1968-2014) and future scenario period (2050-2079) of the 39 GCMs. The SPI is based on the conversion of precipitation data to probabilities using long-term monthly precipitation records calculated on different time scales. SPI is a flexible index for estimating short- and long-term droughts for agricultural and hydrological applications [55-58]. SPI is calculated by fitting an appropriate probability density function to the summed precipitation frequency distribution on the time scale of interest (e.g., 1, 3, 6 and 12 months).

Once the monthly SPI values were determined, the severity of droughts and wet scenarios were evaluated using Table 2.

Table 2. Classification of droughts by SPI value, according to [59].

\begin{tabular}{cc}
\hline SPI Value & Category \\
\hline 2.00 or more & Extremely wet \\
1.50 a 1.99 & Severely wet \\
1.00 a 1.49 & Moderately wet \\
0 a 0.99 & Mildly wet \\
$0 \mathrm{a}-0.99$ & Mild drought \\
$-1.00 \mathrm{a}-1.49$ & Moderate drought \\
$-1.50 \mathrm{a}-1.99$ & Severe drought \\
-2 or less & Extreme drought \\
\hline
\end{tabular}

The changes in drought regime were characterized by the frequency, duration and intensity of droughts (moderate, severe and extreme) computed from the SPI-1 [3,60,61]. In this article, a dry month is considered when the SPI- 1 was less than or equal to the -1.0 threshold. The frequency is referred as the total number of dry months over a defined period. Drought intensity was defined as the average value of the SPIs below the threshold over a defined period, while the duration of a drought event was defined as the consecutive and uninterrupted time period having an SPI-1 below the threshold over a defined period. The changes of drought regime (duration, intensity and frequency) were analyzed for the 2050-2079 period in relation to 1968-2014 period. 


\subsubsection{Hydrological Modeling by GR2M}

Hydrological modeling with GR2M [62] could not be performed for the entire basin due to the lack of information on the flow of the Guayas River. It was performed for the middle and upper sub-basin of the Daule River, however, using data from the Daule at the Capilla hydrological station (Figure 1). The modeling period was 33 years (1982-2014), because of the extent of the temperature data. GR2M is a rainfall-runoff model at a monthly time step, which uses input data such as precipitation and evapotranspiration. Its structure is based on two calibration parameters and two reservoirs: (i) the quadratic soil reservoir $S$ (soil reservoir), which defines the production function with a maximum capacity $X 1$; and (ii) the gravity reservoir $R$ (water reservoir), which specifies the transfer function with $X 2$ (second parameter). $X 2$ determines runoff on output $(Q)$ and the water exchange between surface and subsurface processes [63]. This model has been used in an Andean basin south of Ecuador and adequately represents flow dynamics but overestimates low flows [64].

The GR2M calculation is produced as an output of Equation (10), where the model simulates a complete hydrologic equilibrium [65]:

$$
P=Q+E+F+\Delta S
$$

where $P$ is precipitation, $Q$ is total runoff, $E$ is evapotranspiration, $F$ is total groundwater recharge and $\Delta S$ is the change in soil water content. All components are expressed in $\mathrm{mm} / \mathrm{yr}$. In this study, the GR2M model was divided into two periods: calibration, corresponding to the period 1982-2001, and validation (2002-2014), based on double or split sampling.

Previously, to estimate evapotranspiration time series, a method based on the average monthly temperature of the basin provided by [66] was used. This model is an efficient simplified method based on temperature, latitude and radiation [66,67]; the model formula is:

$$
E=\frac{R_{a}\left(T_{a}+5\right)}{100 \lambda \rho}
$$

where $E$ is in $\mathrm{mm} / \mathrm{d}, R_{a}$ is the shortwave extraterrestrial radiation $\left(\mathrm{kJ} / \mathrm{m}^{2} / \mathrm{d}\right), T_{a}$ is the air temperature $\left({ }^{\circ} \mathrm{C}\right), \lambda$ is the latent heat of vaporization $(\mathrm{kJ} / \mathrm{kg})$ and is the density of water $(\mathrm{kg} / \mathrm{L})$. This method is used to determine evapotranspiration in wet areas, because it provides better estimates in those climatic conditions than in arid areas [68-70].

Finally, the criteria for validation of the GR2M model for the two samples (calibration and validation) were the Nash coefficient and the coefficient of determination. The Nash criterion [71] compares the root mean square deviation of the flow roots with the variance, according to the following formula:

$$
N a s h=100\left[1-\left(\frac{\sum_{l=1}^{N}\left(\sqrt{Q_{0}}-\sqrt{Q_{C}}\right)^{2}}{\sum_{l=1}^{N}\left(\sqrt{Q_{0}}-\sqrt{Q_{M}}\right)^{2}}\right)\right]
$$

where $Q_{0}$ is the observed flow; $Q_{c}$ the flow simulated using the model; $Q_{M}$, average observed flows; and $N$ the observation number.

The coefficient of determination was calculated using the following Equation:

$$
R^{2}=\left[\frac{\operatorname{Cov}(x, y)}{\sigma_{x} \cdot \sigma_{y}}\right]^{2}
$$

where $Q_{0}$ is the observed flow $\sigma_{x}$ and $\sigma_{y} ; R^{2}$ is the coefficient of determination of calculated and observed flows; $\sigma_{x}$ and $\sigma_{x}$, the standard deviation of the flow series; $y$ is the calculated flow; and $x$ is observed flows. Monthly precipitation and temperature from the 39 models were used to project future streamflow. 


\section{Results}

\subsection{Model Performance}

The 39 model datasets were evaluated with respect to the observed data from the control period (1968-2014). Performance before correction showed low correlation between the data observed in the basin and the GCM $(r \sim 0.4, p \leq 0.05)$ for the period 1968-2014, with standard deviation and RMSD higher than $190 \mathrm{~mm} / \mathrm{month}$ and $110 \mathrm{~mm} / \mathrm{month}$ respectively (Figure 3a). Similarly, the temperature data from GCMs without correction presented a correlation coefficient of less than $0.5(p \leq 0.05)$, standard deviation higher than $0.44^{\circ} \mathrm{C} /$ month and RMSD between $0.5-1.2^{\circ} \mathrm{C} /$ month (Figure $3 \mathrm{~b}$ ). However, improved model performance was achieved after correction of the monthly mean data (red circles).
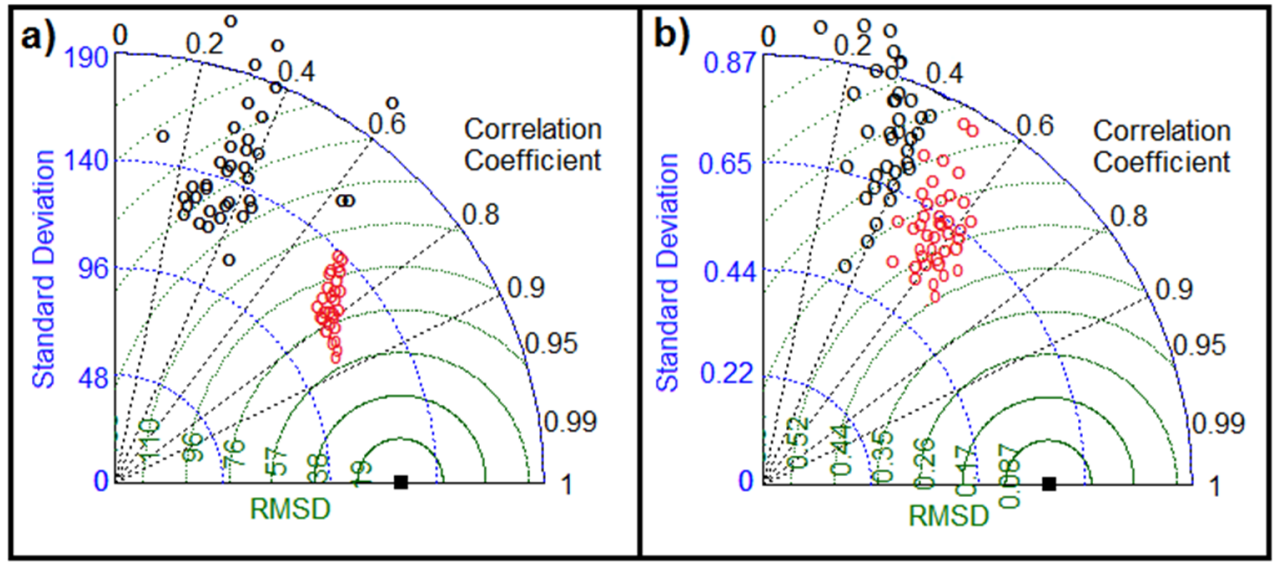

Figure 3. Performance of climate models with uncorrected (black circles) and corrected (red circles) precipitation (a) and temperature (b) monthly mean data using Taylor plot for the period 1968-2014.

The BNU-ESM, inmcm4, FGOALS-g2 and CSIRO-Mk3-6-0 models were selected for the precipitation and temperature datasets. These were chosen because they had the best skill scores $(S \geq 0.69)$. The GCMs selected in this work were also chosen to represent the observed characteristics of the climate system in America [72].

\subsection{Analysis of Climatic Variables}

Analysis of monthly mean precipitation and temperature using the corrected monthly mean data shows that the selected models represent very well the annual cycle of precipitation and temperature observed in the period 1968 to 2014 for the Guayas River basin (Figure 4); the distribution of precipitation is characterized by a wet season (December-May) and dry season (June-November).

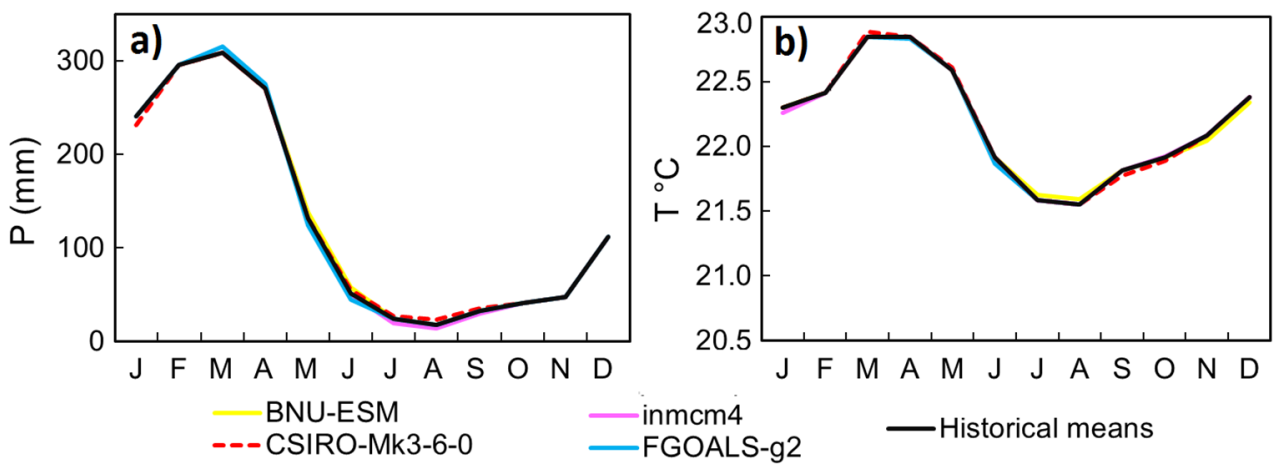

Figure 4. Comparison of monthly mean precipitation (a) and temperature (b) with the four selected climate models and observed data (1968-2014) for the Guayas River basin. 
The average results of the four models predict a warmer climate for the basin, with increases of 1.9 to $2.5^{\circ} \mathrm{C}$ for all months; May and August are the most affected (Figure 5a). Precipitation changes, however, are likely to be much more variable (Figure 5b). Under the RCP8.5 scenario, the four GCMs project average rainfall increases of between 0.3 to $14 \%$ monthly between November and July and decreases of between 0.3 and $10 \%$ between August and October (Figure 5b).
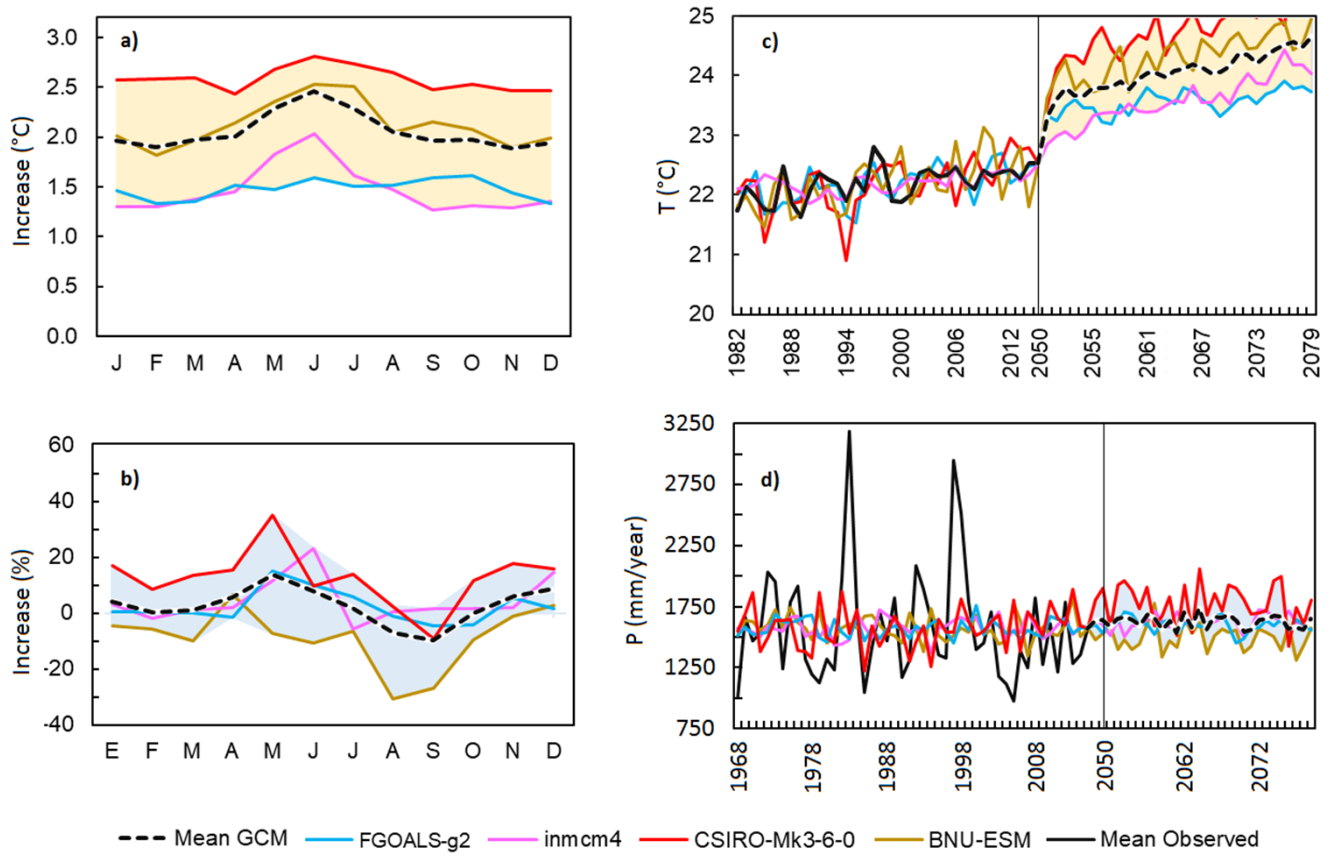

Figure 5. Monthly increases in temperature (a) and precipitation (b) and annual increases in temperature (c) and precipitation (d) projected for the Guayas River basin under four models of the RCP8.5 climate statistics for 2050-2079.

Annual temperature increases in the future (2050-2079) for all GCMs range from 1.3 to $2.6^{\circ} \mathrm{C}$ (Figure 5c). Similarly, on average, the immcm4, FGOALS-g2 and CSIRO-Mk3-6-0 models predict an increase in annual precipitation (2-13\%). However, only the BNU-ESM model predicts a decrease $(5 \%)$ in the basin (Figure $5 \mathrm{~d}$ ). It is important to note that the interannual variability of temperature in the four models can represent the dynamics of the basin (Figure 5c). Nonetheless, the precipitation regimen is not adequately represented (Figure 5d).

\subsection{Changes in Precipitation Characteristics}

Figure 6 shows the cumulative distribution frequency curves (CDF) for drought events (SPI-1 $\leq-1$ ) lasting between 1 and 6 months and wet events (SPI- $1 \geq 1$ ) lasting between 1 and 4 months in the Guayas River basin. Changes in the duration of moderate, severe and extreme drought are found, with three of the four models projecting a decrease (Figure 6a). On average, a decrease of 5 (observed) to 4 months in droughts is expected. On average, wet periods will show a slight increase from 3 (observed) to 3.25 months, although three of the four models suggest they would maintain their duration (Figure 6b). 

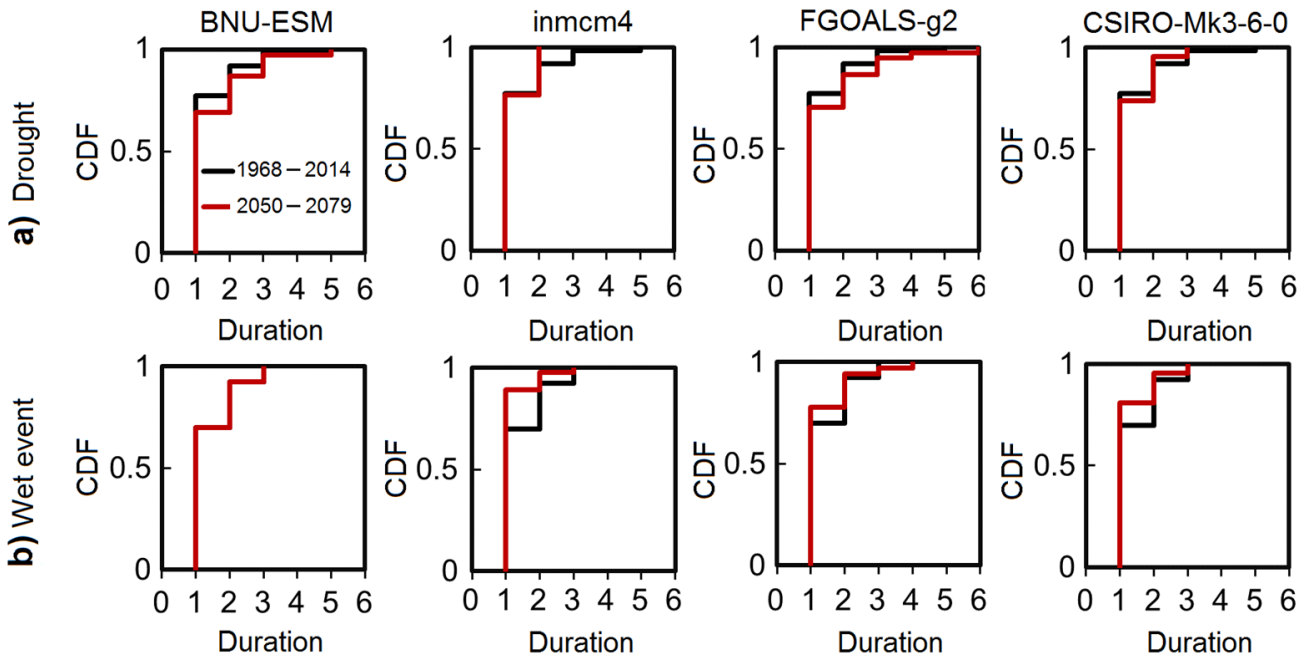

Figure 6. Cumulative distribution frequency (CDF) for drought periods lasting 1 to 6 months (a) and wet periods of 1 to 4 months (b) for the four climate models in the Guayas River basin during the observed (black line) and future (red line) periods.

Evaluation of the mean intensity of droughts (SPI- $1 \leq-1)$ for the four selected GCMs shows an increase in intensity for all CDF curves (Figure 7a), while a decrease for the wet periods is also observed (SPI-1 $\geq 1$ ) (Figure $7 b$ ). Drought is expected to be significantly more intense, as SPI changes from -2.45 to -2.97 for the four selected GCMs. This is 1.21 times higher than the baseline. In contrast, on average, wet periods will be less intense (1.51 times lower than the observed line) for the four models selected.
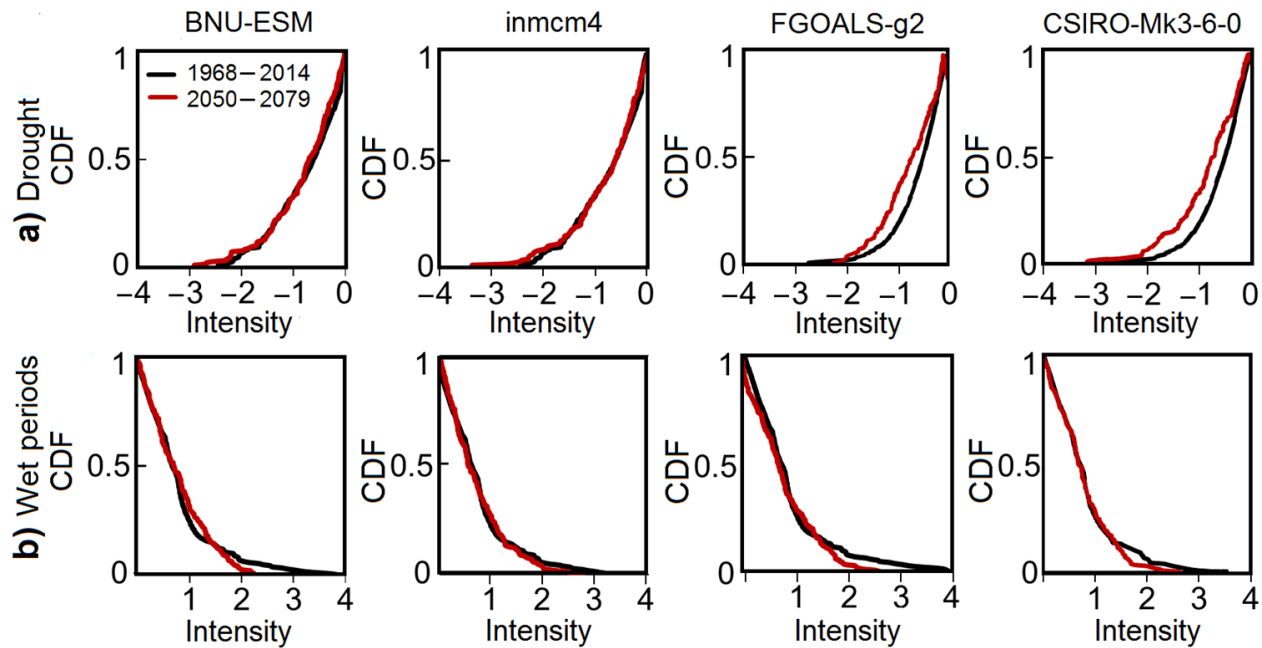

Figure 7. Cumulative distribution frequency curves (CDF) for the intensity of drought (between -4 and 0 ) (a) and wet (between 1 and 4) periods (b), from the four climate models in the Guayas River basin during the observed (black) and future (red) periods.

According to classification of droughts by SPI values (Table 2), on average, the four models show that, in the future, the intensity of extreme and severe droughts will increase slightly, while the intensity of mild and moderate droughts will decrease slightly. In contrast, for wet periods, the extremely wet category will decrease, while severe, moderate and mild wet periods will increase, on average, for 2050-2079 (Figure 8). 


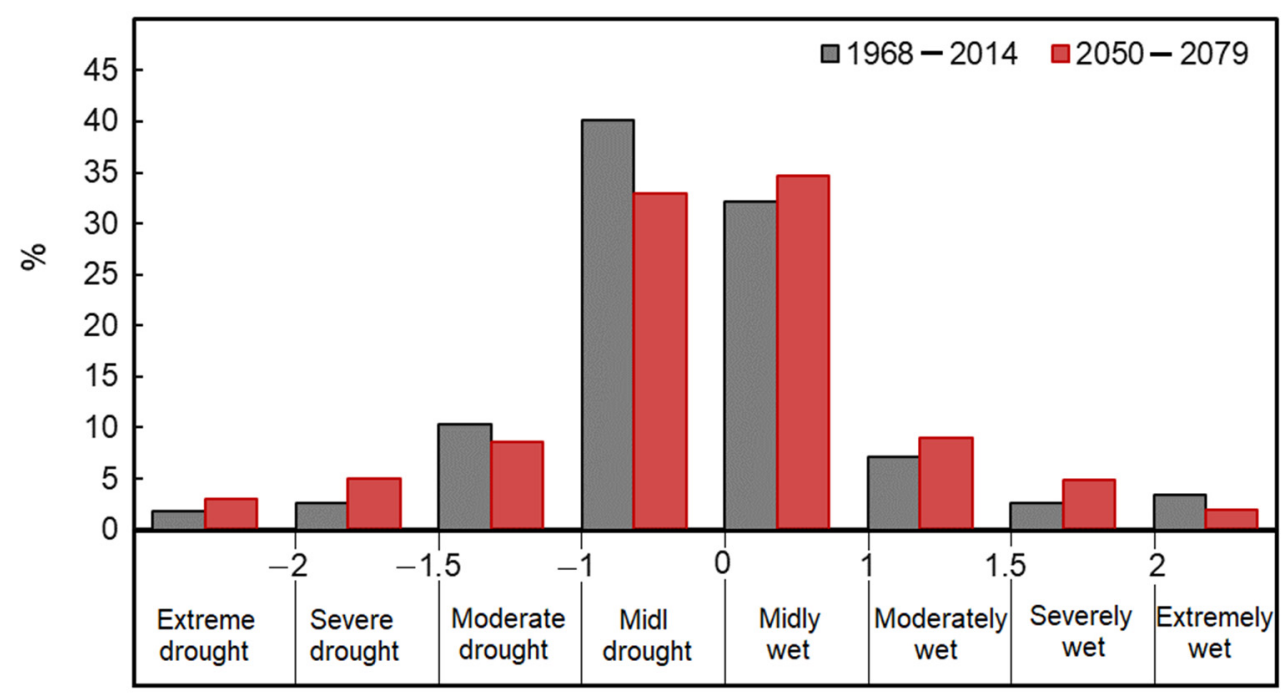

Figure 8. Classification of observed (bar) and future (black line) wet periods and droughts by SPI-1 value.

The spatial distribution of changes in the intensity, duration and frequency of droughts and wet periods SPI-1 in future climate scenarios (2050-2079) for the four selected models was estimated (BNU-ESM, inmcm4, FGOALS-g2 and CSIRO-Mk3-6-0) for the Guayas River basin (Figure 9). Figure 9a shows changes (\%) in the duration of droughts. The plains of the Ecuadorian coast will show a decrease on average $(\sim 20 \%)$, while an increase $(\sim 5 \%)$ will be seen on the slopes of the western Andes Mountains.
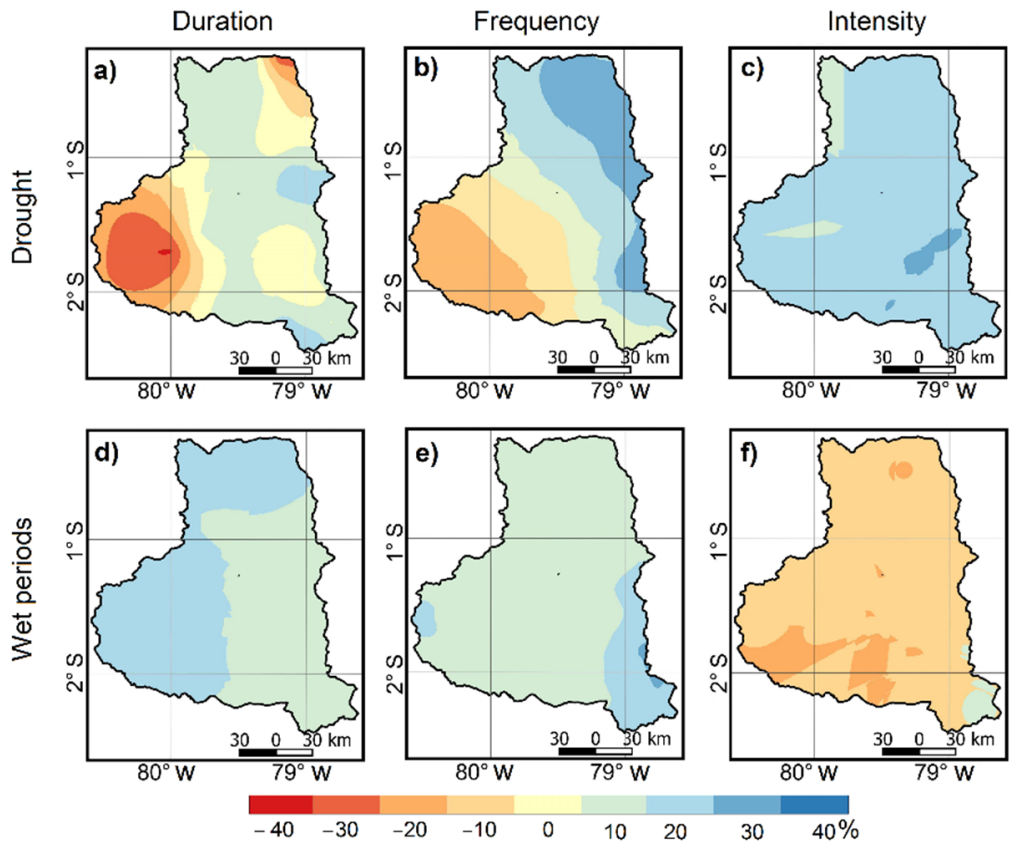

Figure 9. Changes (\%) in the duration, intensity and frequency of droughts and wet periods for the 2050-2079 period in relation to the 1968-2014 period in the Guayas River basin.

Similarly, an average decrease of $\sim 20 \%$ in the frequency of droughts will be expected in the lower basin (coastal plains). In comparison, an increase is shown in the upper basin $(\sim 15 \%)$ (Figure 9 b). The intensity of drought is expected to increase $(\sim 20 \%)$ across the basin (Figure 9c). Wet periods are expected to increase in duration $(\sim 15 \%)$ and frequency $(\sim 10 \%)$ but decrease in intensity $(\sim 12 \%)$, especially in the western parts of the basin (Ecuadorian coast) (Figure 9d-f). 


\subsection{Hydrological Modeling of the Daule River}

The streamflows simulated by GR2M for the calibration and validation phase reveal a good fit, adequately representing the streamflow regime of the Daule River (Figure 10a). The maximum capacity (X1) increased from 7.08 to $7.23 \mathrm{~mm}$, and the exchange parameter $(\mathrm{X} 2)$ increased from 0.88 to $1.20 \mathrm{~mm}$ during validation stage. However, the coefficients of determination $(r=0.87 ; p<0.01)$ and Nash decreased (Figure 10a); this can be attributed to inadequate representation of GCM datasets for estimating extreme streamflows (Figure 10a). The decrease in the GR2M model's performance has also been observed in other studies [64].

The evaluation of streamflows estimated for the future (2050-2079) by the GR2M model for the Daule river, using evapotranspiration calculated by the method [66] and precipitation from BNU-ESM, CSIRO-Mk3-6-0, FGOALS-g2 and inmcm4 models, shows a strong decrease for the low water period. The wet season, however, will be marked by an increase in the streamflow of the Daule River (Figure 11).

The increase and decrease in streamflows are consistent with the temporal distribution of precipitation and the increase in evapotranspiration, associated with the increase in temperature (see Figure 5a). That is, an average of a $7 \%$ increase in precipitation could result in a $69 \%$ increase in river streamflow during flooding periods; conversely, an $8 \%$ decrease in precipitation could result in a 30\% reduction in streamflow for the dry season.

a)

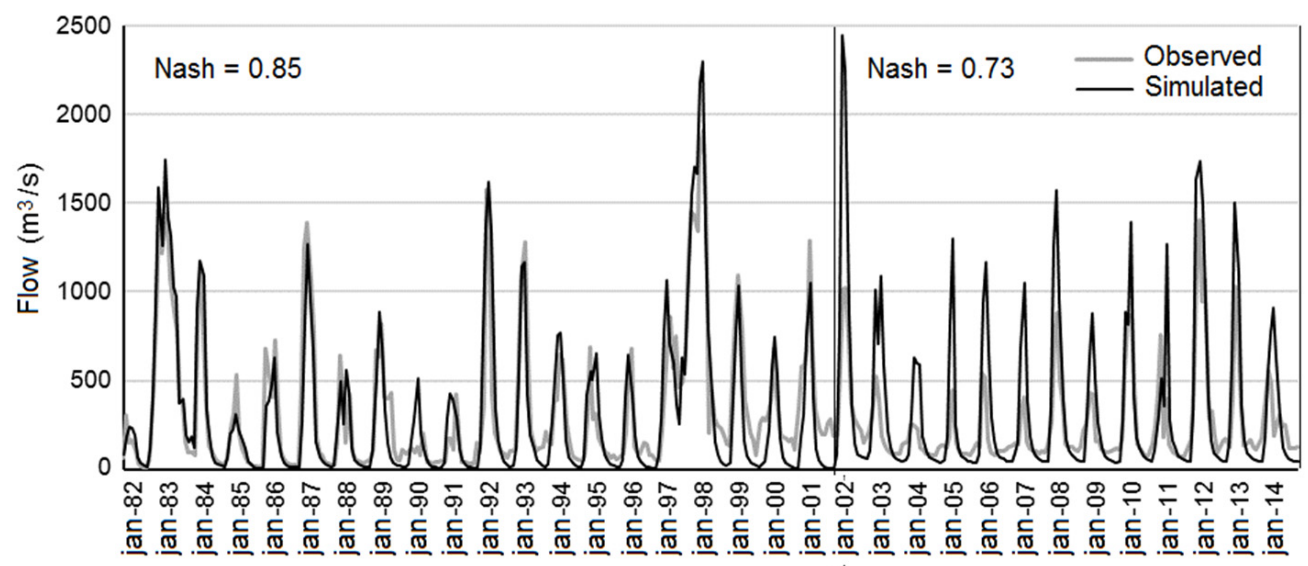

b)

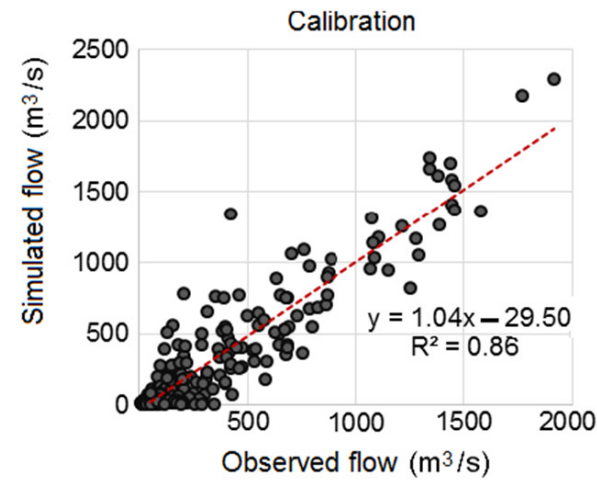

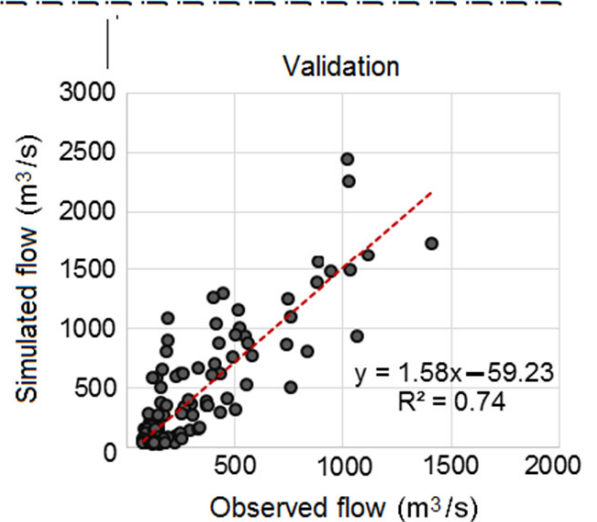

Figure 10. GR2M modeling for the Daule River, Guayas River sub-basin, for the calibration (19822001) and validation (2002-2014) periods. (a) Hydrograph of observed and simulated flows. (b) Correlation. 


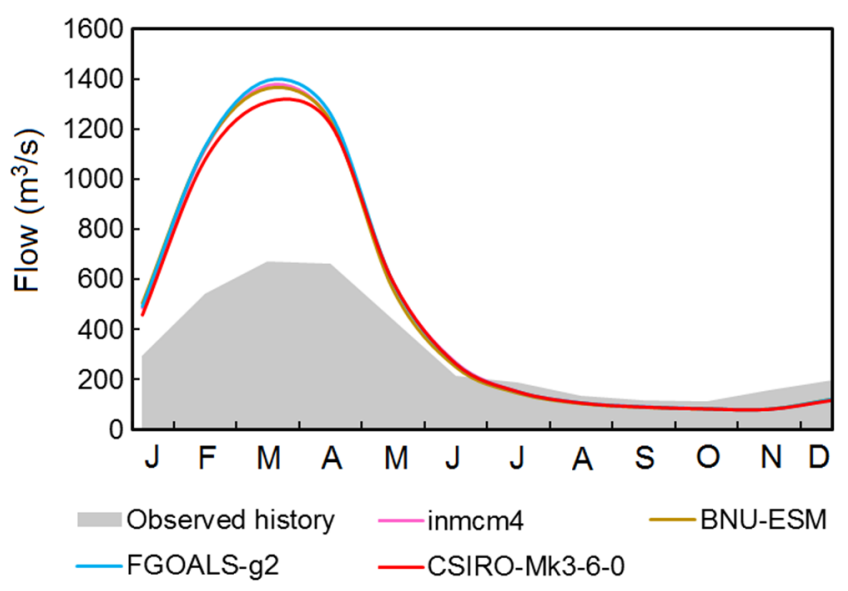

Figure 11. Monthly flow distribution of four RCP8.5 climate models predicted for 2050-2079, with respect to the observed flow distribution (1968-2014) in the Daule River, Guayas River basin.

\section{Discussion}

The results of this study predict a warmer climate $\left(\sim 2{ }^{\circ} \mathrm{C}\right)$ for the Guayas River basin. These increases are consistent with a study conducted for a basin of the Ecuadorian Pacific [73]. The temperature increase in this area could accentuate the heat effect in cities with high population density and high development of the construction sector, such as Guayaquil and Durán, causing greater demand for cooling of buildings and, therefore, greater electricity consumption [74,75]. The basin has high potential for agriculture [36], but the increase in temperature could affect the growth and production patterns of livestock because of water stress [76]. It could also affect crop yields because of a shortage of water caused by greater atmospheric evaporation, which, in turn, would result in an increase in soil water stress [61] and a reduction in surface and groundwater [77].

This study also shows an increase $(7 \%)$ and decrease $(8 \%)$ in precipitation for the wet (flood) and dry periods, respectively. In the flood period, this increase would cause high soil erosion in the upper and middle parts (mountainous region) and sedimentation problems in the lower part of the basin because of the erosive capacity of rainfall in this area [40]. An increase in rainfall during the wet period could affect the cost of agricultural production by making drainage works necessary for banana and sugarcane crops. Meanwhile, a precipitation decrease in the dry period would affect the availability of irrigation water for water-intensive crops, such as rice; this is also true for rain-fed agriculture.

Our findings suggest that future droughts will be a problem because of an increase in the duration (5\%) and frequency (15\%) of droughts around the foothills of the western Andes and part of the Ecuadorian coastal plains. This could further damage productive development, because droughts currently constitute one of the main risks for agricultural and livestock production in the basin [78].

Special consideration must be given to the areas determined to be at moderate to high risk so as to manage their water resources and drought in those areas [79]. Drought-induced restrictions on water use can cause a decrease in crop yields (direct impact), triggering an increase in food costs (indirect impact) [80,81].

On the Ecuadorian coast, wet periods would show a greater effect due to the increase in duration $(\sim 15 \%)$ and frequency $(\sim 10 \%)$. This area has already been affected by human, economic and infrastructure losses caused by floods in 1965, 1972-1973, 1982-1983, 1987, 1992 and 1997-1998 [82]. The increased frequency, duration and intensity of both wet periods and droughts create an imbalance between atmospheric water supply and demand [83-86]. Increased exposure to extreme events, such as droughts and wet periods, under the influence of a warmer climate, is largely consistent with previous studies in various parts of the world [2,3,87].

Another future impact of climate change in the study area will be changes in the flow regimes of the Daule River. A likely increase in evapotranspiration, due to the temperature 
increase, would result in a decrease in streamflows during the dry season (30\%), although an increase in precipitation (7\%) would trigger an increase $(69 \%)$ in streamflows for the flood period. The net result could be a significant reduction in river streamflows during the dry season as a result of climate change [88]. This would trigger an increase in demand for irrigation water in the future [89], especially in productive areas like the Guayas River basin. At the same time, the increased flow during the flood season could affect the functioning of dams and reservoirs [90,91], such as the Daule-Peripa, which is located in the middle part of the basin. Changes in flood and low-water streamflows could be a particularly important impact of climate change in terms of danger to people and the environment [91,92].

This study confirms that the use of selected CMIP5 models can provide a robust assessment of climate change impacts on the precipitation regime in equatorial regions. Nonetheless, it highlights the large uncertainty of future temperature and precipitation in GCMs under a high emissions scenario (RCP8.5) [93,94]. There are additional challenges due to the complexity of droughts $[95,96]$ and GR2M model performance associated with input data uncertainty [62]. Ecuador's environment should also be considered a special case because of the country's location, as it is influenced by the Humboldt current, the El Niño phenomenon, trade wind dynamics, the position of the intertropical convergence zone and the presence of the Andes mountain range [36,97-100], which together give this area great climatic variability.

\section{Conclusions}

In this study, a rigorous process was used to select the BNU-ESM, CSIRO-Mk3-6-0, FGOALS-g2 and inmcm 4 global climate models for the variables precipitation and temperature, based on the evaluation of 39 phase 5 climate models (CMIP5). These models were selected to investigate the impacts of climate change by representing the climate dynamics of the Guayas River basin in Ecuador.

The monthly mean results for the four models project a $\sim 2{ }^{\circ} \mathrm{C}$ increase in temperature and $6 \%$ increase in precipitation for the future (2050-2079) relative to the baseline (1968-2014). The monthly distribution of precipitation provides evidence that the temperature increase will be greatest in the months with the lowest precipitation. These dry conditions can increase the risk of forest fire.

The projected relative increase in rainfall amounts is related to the greater duration and frequency of wet periods. The areas likely to be most affected are located in the great plains of the Ecuadorian coast; this will contribute even more to sedimentation in this region. Droughts are likely to be more intense and frequent, particularly along the western range of the Andes and the coastal plains of Ecuador.

Changes in the hydrological regime of the Daule River are also expected; a 69\% increase in the streamflow for flood periods is identified from Global Climate Models. This probably is due to increased precipitation. In contrast, a decrease of $30 \%$ in the low water level was found because of the potential increase in evapotranspiration caused by higher temperatures. These results indicate the likelihood of problems such as a water deficit during dry periods in the upper part of the basin and increased rainfall and streamflow during flood periods in the lower part of the basin. This information should be considered by stakeholders and policy makers involved in water management when formulating mitigation and adaptation policies to cope with future climate change.

Author Contributions: Conceptualization, M.I.-Y., F.I. and R.Z.; methodology, M.I.-Y., F.I., R.Z. and M.G.-M.; analysis, M.I.-Y. and R.Z.; writing-original draft preparation, M.I.-Y.; writing-review and editing M.I.-Y., F.I., R.Z., M.G.-M. and P.C. All authors have read and agreed to the published version of the manuscript.

Funding: This research received no external funding.

Institutional Review Board Statement: Not applicable.

Informed Consent Statement: Not applicable. 
Data Availability Statement: Publicly available data were analyzed in this study and can be found at the following link: (https:/ / climexp.knmi.nl/plot_atlas_form.py, accessed on 2 October 2020).

Acknowledgments: The authors are grateful to the National Institute of Meteorology and Hydrology (INAMHI) in Ecuador for providing temperature and precipitation data (https://www. serviciometeorologico.gob.ec/, accessed on 2 February 2015). The authors also wish to thank the Coupled Model Intercomparison Project (CMIP5) for providing 39 global circulation models (https: / / climexp.knmi.nl/plot_atlas_form.py, accessed on 2 February 2015). Mercy Ilbay-Yupa thanks the Water Resources Management Group of the Technical University of Cotopaxi (UTC).

Conflicts of Interest: The authors declare no conflict of interest.

\section{References}

1. Vargas-Amelin, E.; Pindado, P. The challenge of climate change in Spain: Water resources, agriculture and land. J. Hydrol. 2014, 518, 243-249. [CrossRef]

2. Wang, G.Q.; Zhang, J.Y.; Jin, J.L.; Pagano, T.C.; Calow, R.; Bao, Z.X.; Liu, C.S.; Liu, Y.L.; Yan, X.L. Assessing water resources in China using PRECIS projections and a VIC model. Hydrol. Earth Syst. Sci. 2012, 16, 231-240. [CrossRef]

3. Leng, G.; Tang, Q.; Rayburg, S. Climate change impacts on meteorological, agricultural and hydrological droughts in China. Glob. Planet. Chang. 2015, 126, 23-34. [CrossRef]

4. Lima, C.H.; Kwon, H.-H.; Kim, J.-Y. A Bayesian beta distribution model for estimating rainfall IDF curves in a changing climate. J. Hydrol. 2016, 540, 744-756. [CrossRef]

5. So, B.-J.; Kim, J.-Y.; Kwon, H.-H.; Lima, C.H.R. Stochastic extreme downscaling model for an assessment of changes in rainfall intensity-duration-frequency curves over South Korea using multiple regional climate models. J. Hydrol. 2017, 553, 321-337. [CrossRef]

6. Zhu, J.; Forsee, W.; Schumer, R.; Gautam, M.R. Future projections and uncertainty assessment of extreme rainfall intensity in the United States from an ensemble of climate models. Clim. Chang. 2012, 118, 469-485. [CrossRef]

7. Hadour, A.; Mahé, G.; Meddi, M. Watershed based hydrological evolution under climate change effect: An example from North Western Algeria. J. Hydrol. Reg. Stud. 2020, 28, 100671. [CrossRef]

8. Khoi, D.N.; Suetsugi, T. Impact of climate and land-use changes on hydrological processes and sediment yield-a case study of the Be River catchment, Vietnam. Hydrol. Sci. J. 2014, 59, 1095-1108. [CrossRef]

9. Arunrat, N.; Pumijumnong, N.; Sereenonchai, S.; Chareonwong, U.; Wang, C. Assessment of climate change impact on rice yield and water footprint of large-scale and individual farming in Thailand. Sci. Total Environ. 2020, 726, 137864. [CrossRef]

10. Taylor, K.E.; Stouffer, R.J.; Meehl, G.A. An overview of CMIP5 and the experiment design. Bull. Am. Meteorol. Soc. 2012, 93, 485-498. [CrossRef]

11. Verichev, K.; Zamorano, M.; Carpio, M. Effects of climate change on variations in climatic zones and heating energy consumption of residential buildings in the southern Chile. Energy Build. 2020, 215, 109874. [CrossRef]

12. Zhang, L.; Zhao, Y.; Hein-Griggs, D.; Janes, T.; Tucker, S.; Ciborowski, J.J.H. Climate change projections of temperature and precipitation for the great lakes basin using the PRECIS regional climate model. J. Great Lakes Res. 2020, 46, 255-266. [CrossRef]

13. Hartmann, D. Chapter 10 global climate models. International geophysics. Climatol. Física Glob. 1994, 56, $254-285$.

14. Wiens, J.; Stralberg, D.; Jongsomjit, D.; Howell, C.; Snyder, M. Niches, models, and climate change: Assessing the assumptions and uncertainties. Proc. Natl. Acad. Sci. USA 2009, 106, 19729-19736. [CrossRef] [PubMed]

15. Vázquez-Patiño, A.; Campozano, L.; Mendoza, D.; Samaniego, E. A causal flow approach for the evaluation of global climate models. Int. J. Climatol. 2020, 40, 4497-4517. [CrossRef]

16. Maurer, E.P. Uncertainty in hydrologic impacts of climate change in the Sierra Nevada, California, under two emissions scenarios. Clim. Chang. 2007, 82, 309-325. [CrossRef]

17. Kirono, D.G.C.; Kent, D.M.; Hennessy, K.J.; Mpelasoka, F. Characteristics of Australian droughts under enhanced greenhouse conditions: Results from 14 global climate models. J. Arid. Environ. 2011, 75, 566-575. [CrossRef]

18. Buytaert, W.; Vuille, M.; Dewulf, A.; Urrutia, R.; Karmalkar, A.; Célleri, R. Uncertainties in climate change projections and regional downscaling in the tropical Andes: Implications for water resources management. Hydrol. Earth Syst. Sci. 2010, 14, 1247-1258. [CrossRef]

19. Keyantash, J.; Dracup, J.A. The quantification of drought: An evaluation of drought indices. Am. Meteorol. Soc. 2002, 83, 1167-1180. [CrossRef]

20. Estrela, M.J.; Pen, D. Multi-annual drought episodes in the Mediterranean (Valencia region) from 1950-1996. A spatio-temporal analysis. Int. J. Climatol. 2000, 20, 1599-1618. [CrossRef]

21. Karambiri, H.; Galiano, S.G.G.; Giraldo, J.D.; Yacouba, H.; Ibrahim, B.; Barbier, B.; Polcher, J. Assessing the impact of climate variability and climate change on runoff in West Africa: The case of Senegal and Nakambe River basins. Atmos. Sci. Lett. 2011, 12, 109-115. [CrossRef]

22. Webster, K.; Kratz, T.K.; Bowser, C.J.; Magnuson, J.J.; Rose, W.J. The influence of landscape position on lake chemical responses to drought in northern Wisconsin. Limnol. Oceanogr. 1996, 41, 977-984. [CrossRef] 
23. Tegegne, G.; Melesse, A.M.; Worqlul, A.W. Development of multi-model ensemble approach for enhanced assessment of impacts of climate change on climate extremes. Sci. Total Environ. 2019, 704, 135357. [CrossRef]

24. Michelson, K.; Chang, H. Spatial characteristics and frequency of citizen-observed pluvial flooding events in relation to storm size in Portland, Oregon. Urban Clim. 2019, 29, 100487. [CrossRef]

25. Jonkman, S.N. Global Perspectives on Loss of Human Life Caused by Floods. Nat. Hazards 2005, 34, 151-175. [CrossRef]

26. Rodrigues, D.T.; Gonçalves, W.A.; Spyrides, M.H.C.; Andrade, L.D.M.B.; de Souza, D.O.; de Araujo, P.A.A.; da Silva, A.C.N.; e Silva, C.M.S. Probability of occurrence of extreme precipitation events and natural disasters in the city of Natal, Brazil. Urban Clim. 2021, 35, 100753. [CrossRef]

27. Wang, R.; Kalin, L.; Kuang, W.; Tian, H. Individual and combined effects of land use/cover and climate change on Wolf Bay watershed streamflow in southern Alabama: Relative impacts of land use/cover and climate change on streamflow. Hydrol. Process. 2014, 28, 5530-5546. [CrossRef]

28. Zhang, L.; Nan, Z.; Xu, Y.; Li, S. Hydrological Impacts of Land Use Change and Climate Variability in the Headwater Region of the Heihe River Basin, Northwest China. PLoS ONE 2016, 11, e0158394. [CrossRef]

29. Aubin, D.; Riche, C.; Water, V.V.; La Jeunesse, I. The adaptive capacity of local water basin authorities to climate change: The Thau lagoon basin in France. Sci. Total Environ. 2018, 651, 2013-2023. [CrossRef] [PubMed]

30. Batisani, N.; Yarnal, B. Rainfall variability and trends in semi-arid Botswana: Implications for climate change adaptation policy. Appl. Geogr. 2010, 30, 483-489. [CrossRef]

31. Savo, V.; Lepofsky, V.S.D.; Benner, J.P.; Kohfeld, K.; Bailey, J.; Lertzman, J.P.B.K.E.K.J.B.K. Observations of climate change among subsistence-oriented communities around the world. Nat. Clim. Chang. 2016, 6, 462-473. [CrossRef]

32. Global Facility for Disaster Reduction and Recovery (GFDRR). Vulnerability, Risk Reduction, and Adaptation to Climate Change Ecuador. Climate Risk and Adaptation Country Profile. 2011. Available online: https://www.gfdrr.org/sites/default/files/ publication/climate-change-country-profile-2011-ecuador.pdf (accessed on 9 June 2021).

33. Elsanabary, M.H.; Gan, T.Y. Evaluation of climate anomalies impacts on the Upper Blue Nile Basin in Ethiopia using a distributed and a lumped hydrologic model. J. Hydrol. 2015, 530, 225-240. [CrossRef]

34. Cadier, E.; Rossel, F.; Sémiond, H.; Gomez, G. Las Inundaciones en la Zona Costera Ecuatoriana: Mecanismos Responsables, Obras de Proteccion Existentes y Previstas. 28 June 1996. Available online: https://horizon.documentation.ird.fr/exl-doc/pleins_ textes / divers14-12/010011839 (accessed on 28 October 2021).

35. Recalde-Coronel, G.C.; Barnston, A.G.; Muñoz, G. Predictability of December-April Rainfall in Coastal and Andean Ecuador. J. Appl. Meteorol. Clim. 2014, 53, 1471-1493. [CrossRef]

36. Rossel, F.; Cadier, E.; Gómez, G. Las inundaciones en la zona costera Ecuatoriana: Causas, obras de proteccion existentes y previstas. Bull. l'Institut Français d'Etudes Andin. 1996, 25, 399-420.

37. Frappart, F.; Bourrel, L.; Brodu, N.; Salazar, X.R.; Baup, F.; Darrozes, J.; Pombosa, R. Monitoring of the Spatio-Temporal Dynamics of the Floods in the Guayas Watershed (Ecuadorian Pacific Coast) Using Global Monitoring ENVISAT ASAR Images and Rainfall Data. Water 2017, 9, 12. [CrossRef]

38. INEC. Resultados del Censo 2010 de Población y Vivienda en el Ecuador; Fascículo Provincial Guayas: Quito, Ecuador, $2010 ;$ pp. 1-8.

39. Fries, A.; Rollenbeck, R.; Bayer, F.; González-Jaramillo, V.H.; Oñate-Valivieso, F.; Peters, T.; Bendix, J. Catchment precipitation processes in the San Francisco valley in southern Ecuador: Combined approach using high-resolution radar images and in situ observations. Theor. Appl. Clim. 2014, 126, 13-29. [CrossRef]

40. Ilbay, M.L.; Zubieta Barragán, R.; Lavado-Casimiro, W. Regionalización de la precipitación, su agresividad y concentración en la cuenca del río Guayas, Ecuador. Granja Rev. Cienc. Vida 2019, 30, 57-76. [CrossRef]

41. Barrera Crespo, P.D.; Mosselman, E.; Giardino, A.; Becker, A.; Ottevanger, W.; Nabi, M.; Arias-Hidalgo, M. Sediment budget analysis of the Guayas River using a process-based model. Hydrol. Earth Syst. Sci. 2019, 23, 2763-2778. [CrossRef]

42. Corporación Andina de Fomento. Las Lecciones de El Niño Ecuador. Mem. Retos Soluc. 1998, 5, 72-73. Available online: https:/ / scioteca.caf.com/bitstream/handle/123456789/675/Las\%20lecciones\%20de\%20El\%20Ni\%C3\%B1o.\%20Ecuador. pdf? sequence $=1 \&$ isAllowed $=y$ (accessed on 28 June 2020).

43. Tutasi, P.; Palma, S.; Cáceres, M. Epipelagic copepod distributions in the eastern equatorial Pacific during the weak La Niña event of 2001. Sci. Mar. 2011, 75, 791-802. [CrossRef]

44. CIIFEN. Estrategia Provincial de Cambio Climático del Guayas. Fase I: Diagnóstico. Vulnerabilidad Social, Económica y Ambiental de la Provincia del Guayas. Informe Técnico. Guayaquil—Ecuador: Gobierno Autónomo Descentralizado Provincial del Guayas. Dirección de Medio Ambiente. 2013. Available online: https://www.researchgate.net/publication/306107811_ Estrategia_Provincial_de_Cambio_Climatico_del_Guayas (accessed on 20 October 2020).

45. CELEC. 25 Años de la Presa Daule-Peripa. Rev. Hidronacion Celec. 2013, 3, 108.

46. Espinoza Villar, J.C.; Ronchail, J.; Guyot, J.L.; Cochonneau, G.; Naziano, F.; Lavado, W.; Oliveira, E.D.; Pombosa, R.; Vauchel, P. Spatio-temporal rainfall variability in the Amazon basin countries (Brazil, Peru, Bolivia, Colombia, and Ecuador). Int. J. Climatol. 2009, 29, 1574-1594. [CrossRef]

47. Moss, R.; Edmonds, J.A.; Hibbard, K.A.; Manning, M.R.; Rose, S.K.; van Vuuren, D.; Carter, T.R.; Emori, S.; Kainuma, M.; Kram, T.; et al. The next generation of scenarios for climate change research and assessment. Nature 2010, 463, 747-756. [CrossRef]

48. Taylor, K.E. Summarizing multiple aspects of model performance in a single diagram. J. Geophys. Res. Space Phys. 2001, 106, 7183-7192. [CrossRef] 
49. Shadmehri Toosi, A.; Doulabian, S.; Ghasemi Tousi, E.; Calbimonte, G.H.; Alaghmand, S. Large-scale flood hazard assessment under climate change: A case study. Ecol. Eng. 2020, 147, 105765. [CrossRef]

50. Wang, H.; Xiao, W.; Wang, Y.; Zhao, Y.; Lu, F.; Yang, M.; Hou, B.; Yang, H. Assessment of the impact of climate change on hydropower potential in the Nanliujiang River basin of China. Energy 2018, 167, 950-959. [CrossRef]

51. Yuan, S.; Quiring, S.M.; Kalcic, M.M.; Apostel, A.M.; Evenson, G.R.; Kujawa, H.A. Optimizing climate model selection for hydrological modeling: A case study in the Maumee River basin using the SWAT. J. Hydrol. 2020, 588, 125064. [CrossRef]

52. Hempel, S.; Frieler, K.; Warszawski, L.; Schewe, J.; Piontek, F. A trend-preserving bias correction-The ISI-MIP approach. Earth Syst. Dyn. 2013, 4, 219-236. [CrossRef]

53. Eisner, S.; Voss, F.; Kynast, E. Statistical bias correction of global climate projections-Consequences for large scale modeling of flood flows. Adv. Geosci. 2012, 31, 75-82. [CrossRef]

54. McKee, T.B.; Doesken, N.J.; Kleist, J. The relationship of drought frequency and duration to time scales. In Proceedings of the 8th Conference on Applied Climatology, Anaheim, CA, USA, 17-22 January 1993; Volume 6.

55. Dutta, D.; Kundu, A.; Patel, N.; Saha, S.; Siddiqui, A. Assessment of agricultural drought in Rajasthan (India) using remote sensing derived Vegetation Condition Index (VCI) and Standardized Precipitation Index (SPI). Egypt. J. Remote Sens. Space Sci. 2015, 18, 53-63. [CrossRef]

56. Lu, J.; Carbone, G.; Gao, P. Detrending crop yield data for spatial visualization of drought impacts in the United States, 1895-2014. Agric. For. Meteorol. 2017, 237-238, 196-208. [CrossRef]

57. Sobral, B.S.; de Oliveira-Junior, J.F.; de Gois, G.; Pereira-Júnior, E.R.; de Bodas Terassi, P.M.; Muniz-Júnior, J.G.R.; Lyra, G.B.; Zeri, M. Drought characterization for the state of Rio de Janeiro based on the annual SPI index: Trends, statistical tests and its relation with ENSO. Atmos. Res. 2019, 220, 141-154. [CrossRef]

58. Zhao, Q.; Chen, Q.; Jiao, M.; Wu, P.; Gao, X.; Ma, M.; Hong, Y. The Temporal-Spatial Characteristics of Drought in the Loess Plateau Using the Remote-Sensed TRMM Precipitation Data from 1998 to 2014. Remote Sens. 2018, 10, 838. [CrossRef]

59. Lloyd-Hughes, B.; Saunders, M.A. A drought climatology for Europe. Int. J. Climatol. 2002, 22, 1571-1592. [CrossRef]

60. Mishra, A.K.; Singh, V.P. A review of drought concepts. J. Hydrol. 2010, 391, 202-216. [CrossRef]

61. Dai, A. Increasing drought under global warming in observations and models. Nat. Clim. Chang. 2013, 3, 52-58. [CrossRef]

62. Niel, H.; Paturel, J.-E.; Servat, E. Study of parameter stability of a lumped hydrologic model in a context of climatic variability. J. Hydrol. 2003, 278, 213-230. [CrossRef]

63. Mouelhi, S.; Michel, C.; Perrin, C.; Andréassian, V. Stepwise development of a two-parameter monthly water balance model. J. Hydrol. 2006, 318, 200-214. [CrossRef]

64. Farfán, J.F.; Palacios, K.; Ulloa, J.; Aviles, A. A hybrid neural network-based technique to improve the flow forecasting of physical and data-driven models: Methodology and case studies in Andean watersheds. J. Hydrol. Reg. Stud. 2020, 27, 100652. [CrossRef]

65. Ibrahim, B. Caractérisation des Saisons de Pluies au Burkina Faso Dans un Contexte de Changement Climatique et Évaluation des Impacts Hydrologiques sur le Bassin du Nakanbé. Ph.D. Thesis, Université Pierre et Marie Curie de Paris (UPMC) et Institut international d'Ingénierie de l'eau et de l'Environnement (2iE) de Ouagadougou, Paris, France, 2012.

66. Oudin, L.; Michel, C.; Anctil, F. Which potential evapotranspiration input for a lumped rainfall-runoff model? J. Hydrol. 2005, 303, 275-289. [CrossRef]

67. Kay, A.; Davies, H. Calculating potential evaporation from climate model data: A source of uncertainty for hydrological climate change impacts. J. Hydrol. 2008, 358, 221-239. [CrossRef]

68. Tegos, A.; Malamos, N.; Koutsoyiannis, D. A parsimonious regional parametric evapotranspiration model based on a simplification of the Penman-Monteith formula. J. Hydrol. 2015, 524, 708-717. [CrossRef]

69. Tegos, A.; Efstratiadis, A.; Koutsoyiannis, D. A parametric model for potential evapotranspiration estimation based on a simplified formulation of the Penman-Monteith equation. In Evapotranspiration-An Overview; Alexandris, S., Ed.; InTech, 2013. Available online: http:/ / www.intechopen.com/books/evapotranspiration-an-overview/a-parametric-model-for-potentialevapotranspiration-estimation-based-on-a-simplified-formulation-of- (accessed on 30 September 2020).

70. Zhou, J.; Wang, Y.; Su, B.; Wang, A.; Tao, H.; Zhai, J.; Kundzewicz, Z.; Jiang, T. Choice of potential evapotranspiration formulas influences drought assessment: A case study in China. Atmos. Res. 2020, 242, 104979. [CrossRef]

71. Nash, J.; Sutcliffe, J. River flow forecasting through conceptual models part I-A discussion of principles. J. Hydrol. 1970, 10, 282-290. [CrossRef]

72. Farjad, B.; Gupta, A.; Sartipizadeh, H.; Cannon, A. A novel approach for selecting extreme climate change scenarios for climate change impact studies. Sci. Total Environ. 2019, 678, 476-485. [CrossRef] [PubMed]

73. Hasan, M.M.; Wyseure, G. Impact of climate change on hydropower generation in Rio Jubones Basin, Ecuador. Water Sci. Eng. 2018, 11, 157-166. [CrossRef]

74. Litardo, J.; Palme, M.; Borbor-Cordova, M.; Caiza, R.; Macias-Zambrano, J.; Hidalgo-Leon, R.; Soriano, G. Urban Heat Island intensity and buildings' energy needs in Duran, Ecuador: Simulation studies and proposal of mitigation strategies. Sustain. Cities Soc. 2020, 62, 102387. [CrossRef]

75. Palme, M.; Inostroza, L.; Villacreses, G.; Cordero, A.L.; Carrasco, C. From urban climate to energy consumption. Enhancing building performance simulation by including the urban heat island effect. Energy Build. 2017, 145, 107-120. [CrossRef]

76. Asare-Nuamah, P.; Botchway, E. Understanding climate variability and change: Analysis of temperature and rainfall across agroecological zones in Ghana. Heliyon 2019, 5, e02654. [CrossRef] 
77. IPCC. Informe especial del IPCC sobre los impactos del calentamiento global de $1.5^{\circ} \mathrm{C}$. Resum. Para Responsab. Políticos 2018, 2, $1-32$.

78. INEC. Libro Metodológico del Instituto Nacional de Estadística y Censo. Metodología de la Encuesta de Superficie y Producción Agropecuaria Continúa ESPAC; Instituto Nacional de Estadística y Censos (INEC): Loja, Ecuador, 2014.

79. Valverde-Arias, O.; Garrido, A.; Valencia, J.L.; Tarquis, A. Using geographical information system to generate a drought risk map for rice cultivation: Case study in Babahoyo canton (Ecuador). Biosyst. Eng. 2018, 168, 26-41. [CrossRef]

80. Stagge, J.H.; Kohn, I.; Tallaksen, L.M.; Stahl, K. Modeling drought impact occurrence based on meteorological drought indices in Europe. J. Hydrol. 2015, 530, 37-50. [CrossRef]

81. Van Loon, A.F. Hydrological drought explained. Wiley Interdiscip. Rev. Water 2015, 2, 359-392. [CrossRef]

82. Demoraes, F.; D'Ercole, R. Cartografía de las amenazas de origen natural por cantón en el Ecuador. Inf. Prelim. COOPI OXFAM Sist. Integr. Indic. Soc. Ecuad. (SIISE) 2001, 1, 65.

83. Boonwichai, S.; Shrestha, S.; Babel, M.S.; Weesakul, S.; Datta, A. Evaluation of climate change impacts and adaptation strategies on rainfed rice production in Songkhram River Basin, Thailand. Sci. Total Environ. 2018, 652, 189-201. [CrossRef] [PubMed]

84. Dai, A. Drought under global warming: A review. Wiley Interdiscip. Rev. Clim. Chang. 2011, 2, 45-65. [CrossRef]

85. Teixeira, E.I.; Fischer, G.; van Velthuizen, H.; Walter, C.; Ewert, F. Global hot-spots of heat stress on agricultural crops due to climate change. Agric. For. Meteorol. 2013, 170, 206-215. [CrossRef]

86. Won, J.; Choi, J.; Lee, O.; Kim, S. Copula-based Joint Drought Index using SPI and EDDI and its application to climate change. Sci. Total Environ. 2020, 744, 140701. [CrossRef] [PubMed]

87. Shahid, S.; Wang, X.-J.; Bin Harun, S.; Shamsudin, S.B.; Ismail, T.; Minhans, A. Climate variability and changes in the major cities of Bangladesh: Observations, possible impacts and adaptation. Reg. Environ. Chang. 2015, 16, 459-471. [CrossRef]

88. Huntington, T. Climate warming could reduce runoff significantly in New England, USA. Agric. For. Meteorol. 2003, 117, $193-201$. [CrossRef]

89. Du Plessis, J.A.; Kalima, S.G. Modelling the impact of climate change on the flow of the Eerste River in South Africa. Phys. Chem. Earth Parts A/B/C 2021, 11, 103025. [CrossRef]

90. Cui, T.; Tian, F.; Yang, T.; Wen, J.; Khan, M.Y.A. Development of a comprehensive framework for assessing the impacts of climate change and dam construction on flow regimes. J. Hydrol. 2020, 590, 125358. [CrossRef]

91. Gierszewski, P.J.; Habel, M.; Szmańda, J.B.; Luc, M. Evaluating effects of dam operation on flow regimes and riverbed adaptation to those changes. Sci. Total. Environ. 2019, 710, 136202. [CrossRef]

92. Kay, A.; Griffin, A.; Rudd, A.; Chapman, R.; Bell, V.; Arnell, N. Climate change effects on indicators of high and low river flow across Great Britain. Adv. Water Resour. 2021, 151, 103909. [CrossRef]

93. Shen, M.; Chen, J.; Zhuan, M.; Chen, H.; Xu, C.-Y.; Xiong, L. Estimating uncertainty and its temporal variation related to global climate models in quantifying climate change impacts on hydrology. J. Hydrol. 2018, 556, 10-24. [CrossRef]

94. Almazroui, M.; Islam, M.N.; Saeed, F.; Alkhalaf, A.K.; Dambul, R. Assessing the robustness and uncertainties of projected changes in temperature and precipitation in AR5 Global Climate Models over the Arabian Peninsula. Atmos. Res. 2017, 194, 202-213. [CrossRef]

95. Campozano, L.; Ballari, D.; Montenegro, M.; Avilés, A. Future meteorological droughts in Ecuador: Decreasing trends and associated spatio-temporal features derived from CMIP5 models. Front. Earth Sci. 2020, 8, 17. Available online: https: //www.frontiersin.org/articles/10.3389/feart.2020.00017/full (accessed on 31 May 2021). [CrossRef]

96. Xu, K.; Wu, C.; Zhang, C.; Hu, B.X. Uncertainty assessment of drought characteristics projections in humid subtropical basins in China based on multiple CMIP5 models and different index definitions. J. Hydrol. 2021, 600, 126502. [CrossRef]

97. Ilbay-Yupa, M.; Lavado-Casimiro, W.; Rau, P.; Zubieta, R.; Castillón, F. Updating regionalization of precipitation in Ecuador. Theor. Appl. Climatol. 2021, 143, 1513-1528. [CrossRef]

98. Pourrut, P. Los climas del Ecuador: Fundamentos explicativos. In ORSTOM y Programa Nacional de Regionalización Agraria del Ministerio de Agricultura y Ganadería Quito, Quito, Ecuador; 1983. Available online: https://horizon.documentation.ird.fr/exl-doc/ pleins_textes/divers11-10/21848.pdf (accessed on 28 October 2021).

99. Poveda, G.; Mesa, Ó.J. Las fases extremas del fenómeno ENSO (El Niño y La Niña) y su influencia sobre la hidrología de Colombia. Tecnol. Cienc. Agua 1996, 11, 21-37.

100. Vuille, M.; Bradley, R.S.; Keimig, F. Climate Variability in the Andes of Ecuador and Its Relation to Tropical Pacific and Atlantic Sea Surface Temperature Anomalies. J. Clim. 2000, 13, 2520-2535. [CrossRef] 